The stratigraphic position and the age of the Ordovician organic-rich intervals in the northern Hudson Bay, Hudson Strait and Foxe basins - evidence from graptolites

\author{
Shunxin Zhang ${ }^{1}$ and John F. Riva ${ }^{2}$ \\ ${ }^{1}$ Canada - Nunavut Geoscience Office, PO Box 2319, 1106 Inuksugait IV, $1{ }^{\text {st }}$ floor, Iqaluit, \\ Nunavut X0A 0H0, Canada; shunxin.zhang@canada.ca \\ ${ }^{2}$ INRS Centre Eau, Terre, Environnement, 490, rue de la Couronne, Québec, QC G1K 9A9, \\ Canada; John.Riva@ete.inrs.ca
}

Correspondence author:

Shunxin Zhang

PO Box 2319, 1106 Inuksugait IV, $1^{\text {st }}$ floor, Iqaluit, Nunavut X0A 0H0, Canada;

Phone: (867) 975-4579

Fax: (867) 979-0708

Email: shunxin.zhang@canada.ca

NRCan, LMS contribution number 20170297 


\title{
The stratigraphic position and the age of the Ordovician organic-rich intervals in the northern Hudson Bay, Hudson Strait and Foxe basins - evidence from graptolites
}

\author{
Shunxin Zhang and John F. Riva
}

\begin{abstract}
Graptolites recovered from the organic-rich intervals, previously named the Boas River Formation in the Upper Ordovician succession on Southampton, Akpatok and southern Baffin islands provide a reliable age assessment for the Upper Ordovician petroleum source rocks in the northern Hudson Bay, Hudson Strait and Foxe basins. They are characterised by Anticostia lata and An. hudsoni in the lower Red Head Rapids Formation on Southampton Island; An. decipiens and Rectograptus socialis in the lower Foster Bay Formation on Akpatok Island; and Diplacanthograptus spiniferus and Amplexograptus praetypicalis in the lower Amadjuak Formation on southern Baffin Island. These data suggest that the organic-rich intervals in the northern Hudson Bay and Hudson Strait basins can be correlated to the Dicellograptus anceps and Paraorthograptus pacificus zones of the upper Katian, and the horizon in the Foxe Basin to the Diplacanthograptus spiniferus Zone of the lower Katian. The Boas River Formation is not deemed appropriate to use as it occurs as an organic-rich interbed in different stratigraphic units in different basins; therefore, it is suggested to abandon it as a stratigraphic term.
\end{abstract}

Keywords: Ordovician organic-rich intervals; graptolites; northern Hudson Bay Basin; Foxe Basin; Hudson Strait Basin 


\section{Introduction}

The Hudson Bay, Hudson Strait and Foxe basins are three intracratonic basins in northern Canada (Pinet et al. 2013; Fig. 1). The basins are commonly filled by shallow marine Paleozoic sediments, which are represented by the Paleozoic succession exposed on Southampton, Akpatok and Baffin islands, and the Melville Peninsula. To the south, the Hudson Bay Basin succession is also exposed on Hudson Bay Lowlands in northern Ontario and northeastern Manitoba. Although these basins have never produced hydrocarbons, recent studies have proved significant hydrocarbon source rock potential in the Upper Ordovician succession (Macauley 1986, 1987; Macauley et al. 1990; Zhang 2008, 2012; Zhang and Mate 2015; Lavoie et al. 2013, 2015; Reyes et al. 2016).

The Upper Ordovician hydrocarbon source rocks were known as the "Boas River shale" or the Boas River Formation, and stratigraphically were interpreted to occur at the same level in the three basins (Heywood and Sanford 1976; Sanford and Grant 1990; 1998, 2000) (Fig. 2). More recently, however, this stratigraphic correlation has been revised based on detailed field investigations and studies of conodont microfossils on Southampton, southern Baffin and Akpatok islands, indicating that the number, age and stratigraphic position of the organic-rich intervals vary from basin to basin (Zhang 2008, 2011, 2012, 2018) (Fig. 2). It is worth noting that the type locality of the Boas River Formation was also revisited during these field investigations, and it was found that it did not provide sufficient stratigraphic support to maintain the name Boas River Formation as a valid stratigraphic unit (Zhang 2008).

This paper reports on the graptolites from outcrops on Southampton and southern Baffin islands and from rubble on Akpatok Island, provides further support for the conclusion of Zhang $(2008,2011,2012,2018)$ regarding the stratigraphic position and relative age for the organic- 
rich intervals in the three intracratonic basins in northern Canada from the graptolite point of view, and proposes abandoning the Boas River Formation as a stratigraphic unit.

\section{Organic-rich intervals in the Upper Ordovician succession in the northern Hudson Bay, Hudson Strait and Foxe Basins}

The Upper Ordovician strata are dominated by various shallow marine carbonates in which thin, organic-rich argillaceous limestone or limy shale intervals are present. The stratigraphy is divided upward into the Bad Cache Rapids Group, the "Boas River shale", the Churchill River Group and the Red Head Rapids Formation in the northern Hudson Bay Basin as exposed on Southampton Island (Heywood and Sanford 1976) (Fig. 2). A similar carbonatedominated stratigraphic succession was partitioned into the Amadjuak, Boas River, Akpatok, and Foster Bay formations in Foxe Basin and Hudson Strait Basin cropping out on southern Baffin Island, Melville Peninsula and Akpatok Island (Sanford and Grant 1990, 1998, 2000) (Fig. 2). Generally, the Bad Cache Rapids and Churchill River groups and their equivalent Amadjuak and Akpatok formations are limestone units; the Red Head Rapids Formation and its counterpart Foster Bay Formation are dolomitic limestone and dolostone units (Heywood and Sanford 1976; Sanford and Grant 1990, 1998, 2000; Zhang 2008, 2011, 2012, 2013, 2018). The "Boas River shale" or the Boas River Formation is a thin, organic-rich unit; its stratigraphic position and age have been significantly revised (Zhang 2008, 2011, 2012, 2018), since the unit was first introduced (Heywood and Sanford 1976) and formally used (Sanford and Grant 1990, 1998, 2000). 


\section{Organic-rich intervals on Southampton Island, the northern Hudson Bay Basin}

The "Boas River shale" is a thin unit of organic-rich brown laminated argillaceous limestone and shale more than one meter in thickness (Zhang 2008). It was first recognised in a stream cut of Boas River in the central part of Southampton Island, and its stratigraphic position was placed between the Bad Cache Rapids and the Churchill River groups (Heywood and Sanford 1976); and then formally named the Boas River Formation (Sanford and Grant 1990). The "Boas River shale" has yielded the graptolite Glyptograptus hudsoni Jackson and trilobite Pseudogygites sp. (Jackson 1971). Several decades later, three thin organic-rich intervals, $>1 \mathrm{~m}$, 0.3-0.4 $\mathrm{m}$ and $0.35-0.5 \mathrm{~m}$ in upward order, were identified in a circa $17 \mathrm{~m}$ interval in unit 1 of the lower part of the Red Head Rapids Formation in a creek in the Cape Donovan area, northeastern Southampton Island (Zhang 2008). These excellent petroleum source rocks yield maximum and average total organic carbon (TOC) of $17.3 \%$ and $9.8 \%, 34.1 \%$ and $22.4 \%$, and $31 \%$ and $18.3 \%$ in the lower, middle and upper intervals, respectively (Zhang 2008). Based on the unique laminated nature of organic-rich argillaceous limestone, the trilobites and the conodonts, the lower of the three organic-rich intervals was correlated to the "Boas River shale" (Zhang 2008, 2011). Therefore, the "Boas River shale" is located within the unit 1 of the lower Red Head Rapids Formation, rather than between Bad Cache Rapids and Churchill River groups (Fig. 2). The "Boas River shale" together with the Red Head Rapids Formation was biostratigraphically correlated with the conodont Aphelognathus divergens Zone of the upper Katian (Zhang 2011) (Fig. 3). 


\section{Organic-rich interval on Akpatok Island, the Hudson Strait Basin}

A bituminous, brown, argillaceous limestone with a thickness of $4.5 \mathrm{~m}$ was described above the high sea level at section II, i.e. locality 3A in Zhang (2018, fig. 3B), in a gully to the south of the Premium Homestead Akpatok L-26 well location; and it was correlated to the "Boas River shale" between the Bad Cache Rapids and the Churchill River groups by Workum et al. (1976). Recently, field investigation at the same locality proved that this bituminous, brown, argillaceous limestone is not an outcrop, but a pile of rubble, and that the bituminous, brown, argillaceous limestone only occurs at the bottom of the pile (Zhang and Mate 2015; Zhang 2018). The rubble contains maximum and average TOC 4.19\% and 3.11\% (Zhang and Mate 2015). According to the conodonts and graptolite preserved in the organic-rich limestone rubble, Zhang (2018) concluded that the organic-rich rubble is most likely from the Foster Bay Formation, rather than from between the Amadjuak and Akpatok formations, and biostratigraphically the Foster Bay Formation is correlated with the conodont Aphelognathus divergens Zone of the upper Katian (Fig. 3).

\section{Organic-rich interval on southern Baffin Island, the Foxe Basin}

Macauley (1987) described an organic-rich interval from the Jordan River section on southern Baffin Island. The interval was designated as the Boas River Formation without formal diagnosis and description, and its stratigraphic position was suggested to be between the Amadjuak and Akpatok formations by Sanford and Grant (1990, 1998, 2000) (Fig. 2). However, Riva (2000) in the same volume (McCracken and Bolton 2000) as Sanford and Grant (2000) demonstrated that the stratigraphic position of this organic-rich interval is near the base of Amadjuak Formation. Zhang (2012) visited the Jordan River section and reported a brown-black 
shale with a thickness of less than two meters and containing maximum and average TOC $12.97 \%$ and 7.8\% in the lower Amadjuak Formation. Thus, both Riva (2000) and Zhang (2012) concur that the organic-rich interval on southern Baffin Island in the Foxe Basin is in the lower Amadjuak Formation instead of between the Amadjuak and Akpatok formations (Fig. 2). In the limestone beneath this organic-rich interval at the Jordan River section, the typical Amadjuak Fisherites-Maclurites Fauna was found (Zhang 2012), and one specimen of conodont Amorphognathus superbus Rhode was recovered (McCracken 2000), suggesting a correlation of the organic-rich interval in the Foxe Basin with the lower Katian conodont Amorphognathus superbus Zone (Fig. 3).

\section{Graptolites in the Upper Ordovician organic-rich intervals on Southampton, Akpatok and southern Baffin islands}

\section{Graptolites on Southampton Island, the northern Hudson Bay Basin}

As mentioned above, the lower of the three organic-rich intervals identified in unit 1 of the lower Red Head Rapids Formation at Cape Donovan section on Southampton Island was correlated to the "Boas River shale" (Zhang 2008, 2011). This correlation was based on the unique laminated nature of organic-rich argillaceous limestone and the occurrence of the trilobite Pseudogygites hudsoni Ludvigsen in the lower organic-rich interval at the Cape Donovan section and the "Boas River shale" at the Boas River section (Zhang 2008, fig. 9), which is the only interval where graptolites occur.

Jackson (1971) described a new species of graptolite, Glytptograptus hudsoni (subsequently transferred to Anticostia Stewart and Mitchell 1997), from a slab of limestone of 
unknown location and stratigraphic position on Southampton Island, but its stratigraphic position was referred to as the "oil shale horizon" of latest Ordovician age (Nelson and Johnson 1966).

More recently, on Southampton Island, graptolites were found in limestone interbeds within the "Boas River shale", i.e. the lower of the three organic-rich intervals (Zhang, 2008, 2011). The limestone interbeds are rich in graptolites, but contain only Anticostia lata (Elles and Wood 1906) (Figs. 4A, 4B) (senior synonym of Climacograptus inuiti Cox, 1933a; see Štorch et al. 2011 for details of genus transfer). Anticostia hudsoni, however, is not present among the recovered specimens.

Riva (1988) noted that Anticostia lata, An. prominens, and An. cf. An. hudsoni occurred together in the An. prominens Zone in the Vauréal Formation on Anticosti Island. Thus, the slab of limestone from an unknown locality on Southampton Island containing An. hudsoni (Jackson 1971) was most likely from the same stratigraphic level as the limestone interbeds yielding the graptolite An. lata in the lower organic-rich interval of the Red Head Rapids Formation reported by this study. Moreover, the presence of both An. lata and An. hudsoni provided a biostratigraphic connection between the lower organic-rich interval on Southampton Island and the An. prominens Zone on Anticosti Island.

\section{Graptolites on Akpatok Island, the Hudson Strait Basin}

A "chocolate-coloured limestone" bed yielding the graptolite Anticostia lata described by Cox (1933a) occurs at an elevation between 143 and $144 \mathrm{~m}$ in a creek at the southern end of Akpatok Island (Cox 1933b). Unfortunately, there was no chance to visit this locality during the field investigations (Zhang and Mate 2015, Zhang 2018). 
The graptolites reported here from Akpatok Island were found in the bituminous, argillaceous limestone rubble at the same locality described as section II by Workum et al. (1976). Most graptolites found in the samples are very fragmentary, and only few good specimens are identifiable. This graptolite fauna includes Amplexograptus decipiens Riva (subsequently transferred to the genus Anticostia Stewart and Mitchell 1997) (Figs. 4E, 4F) and Rectograptus socialis (Lapworth) (Figs. 4C, 4D). On Anticosti Island, the former is associated with Anticostia lata in the An. prominens Zone (Riva 1988; fig. 1), and the latter's highest occurrence is in the lower part of the zone (McLaughlin et al. 2016; fig. 2). Therefore, the bituminous, argillaceous limestone rubble recovered by this study could be correlated with the “chocolate-coloured limestone" bed of Cox (1933b), an interval in the Upper Ordovician Foster Bay Formation on Akpatok Island (Zhang 2018). As a result, both the bituminous, argillaceous limestone rubble reported herein and the "chocolate-coloured limestone" band of Cox (1933b) can be correlated with the Anticostia prominens Zone on Anticosti Island (Riva 1988).

The Anticostia prominens Zone on Anticosti Island was related to the Dicellograptus anceps Zone of Scotland and the Paraorthograptus pacificus Zone of Siberia, Kazakhstan and China (Riva 1988). This correlation is partially followed by this present study, i.e. the lower organic-rich interval of the Red Head Rapids Formation on Southampton Island and the organicrich interval of the Foster Bay Formation on Akpatok islands could be correlated to an uncertain interval within the Dicellograptus anceps and Paraorthograptus pacificus zones, most likely within the Paraorthograptus pacificus Zone (Fig. 3). This is based on 1) the fauna reported above, particularly the presence of Anticostia lata and An. hudsoni in the lower organic-rich interval of the Red Head Rapids Formation on Southampton Island and of An. lata and An. decipiens in the organic-rich interval of the Foster Bay Formation on Akpatok islands, and 2) the 
correlation of these organic-rich intervals to the conodont Aphelognathus divergens Zone (Zhang 2011, 2018), which is, in turn, broadly correlated to the Paraorthograptus pacificus Zone (Cooper and Sadler 2012).

Reports on the occurrence of Anticosti hudsoni and An. decipiens are rare, and their worldwide stratigraphic distribution is unclear. Globally, the stratigraphic distribution of An. lata varies from section to section. Anticostia lata is generally seen in the Dicellograptus anceps Zone, such as in north-central Nevada, USA (Štorch et al. 2011) and on the Canadian Arctic Islands (Melchin 1987), but its highest occurrence has been found to be in the Normalograptus extraordinarius Zone of the Hirnantian in north-central Nevada, USA (Štorch et al. 2011) and China (Chen et al. 2000a, 2005). In some cases Anticostia lata is restricted to the Dicellograptus complexus Subzone of the Dicellograptus anceps Zone, as seen in Scotland (Williams 1982a, 1982b, 1987), or the Dicellograptus ornatus Zone in Idaho, USA (Mitchell et al. 2003). Therefore, based on the known graptolite species from Southampton and Akpatok islands, the biostratigraphic position of the organic-rich interval in the lower Red Head Rapids and Foster Bay formations could extend above the Paraorthograptus pacificus Zone, but it is definitely much higher than that in the lower Amadjuak Formation on southern Baffin Island (see discussion below).

\section{Graptolites on southern Baffin Island, the Foxe Basin}

Two graptolite species, Climacograptus (Diplacanthograptus) spiniferus Ruedeman and Amplexograptus praetypicalis Riva, were reported from the organic-rich interval in the lower Amadjuak Formation on southern Baffin Island; based on the graptolite fauna, the organic-rich interval was correlated with lower Diplacanthograptus spiniferus Zone of latest Mohawkianearly Edenian age (Riva 2000). 
The graptolites found during the recent field investigation (Zhang 2012) are well preserved on the weathered bedding plane of black shale in outcrops of organic-rich interval of the lower Amadjuak Formation. All specimens belong to one of the two species reported by Riva (2000), i.e. Amplexograptus praetypicalis (Figs. 4G, 4H). Therefore, this present study agrees with the stratigraphic correlation of the organic-rich interval in the Amadjuak Formation with the lower Diplacanthograptus spiniferus Zone suggested by Riva (2000); the zone is correlated to the lower Katian by the GTS of 2012 (Fig. 3).

Regionally, the graptolites found in the organic-rich interval in the Amadjuak Formation on southern Baffin Island suggest a biostratigraphic connection to the lower Utica Shale in St. Lawrence Lowlands of Quebec (Riva 1969) and the Indian Castle Member of the Utica Shale in New York State (Goldman et al. 1999), in which Diplacanthograptus spiniferus is omnipresent.

Outside North America, Amplexograptus praetypicalis was not only reported from the Diplacanthograptus spiniferus Zone, and possibly from a zone below, the Diplacanthograptus lanceolatus Zone, in Xinjiang, China; however, the distributions of Di. spiniferus and Di. lanceolatus do not overlap in that region (Chen et al. 2000b). Therefore, it is only natural to correlate the organic-rich interval in the lower Amadjuak Formation on southern Baffin Island yielding both Am. praetypicalis and Di. spiniferus to the Diplacanthograptus spiniferus Zone.

\section{Proposal to abandon the name Boas River Formation}

As mentioned above, the name "Boas River shale" was introduced by Heywood and Sanford (1976) for a thin unit of organic-rich brown shale and laminated argillaceous limestone in a stream cut of the Boas River on Southampton Island. Afterwards, it was formally named Boas River Formation (Sanford and Grant 1990). Since then, the name Boas River Formation has 
been widely used for the Upper Ordovician organic-rich units in the northern Hudson Bay, Foxe Basin and Ungava Bay areas (Sanford and Grant 1990, 1998, 2000), as well as in Hudson Bay Lowlands (Armstrong and Lavoie 2010a, 2010b; Lavoie et al. 2013; McCracken et al. 2013; Hahn et al. 2016, 2017; Nicolas and Armstrong 2017). All the known localities with the exposed Upper Ordovician organic-rich intervals in these areas, except for Hudson Bay Lowlands, were visited by Zhang (2008, 2011, 2012, 2018; Zhang and Mate 2015). Various stratigraphic problems have become apparent in using the Boas River Formation in the region, and the name was not used in recent studies (Zhang 2008, 2011, 2012, 2018). It is here suggested to abandon this stratigraphic term in the areas covered by this study. The main points are:

- $\quad$ Type locality

At the type locality of the Boas River Formation, the exposure is very poor (Zhang 2008, figs. $8 \mathrm{a}$ and $8 \mathrm{~b}$ ). The strata above the Boas River Formation are eroded off, and those below not exposed. The type section does not show a stratigraphic contact between the Bad Cache Rapids and the Churchill River groups as interpreted by Heywood and Sanford (1976).

- Lithostratigraphy

○ Three oil shale intervals were identified in unit 1 , thin-layered and laminated argillaceous limestone interbedded with oil shales, of the Red Head Rapids Formation in a well exposed stream cut section in the Cape Donovan area on Southampton Island (Zhang 2008, 2011). Based on its unique laminated lithology and distinctive trilobite and conodonts, the Boas River Formation was correlated to the lower of the three organic-rich intervals in unit 1 of the Red Head Rapids Formation (Zhang 2008, 2011). 
- The stratigraphic position of the Boas River Formation is in the lower Amadjuak Formation, right above the lowest occurrence of the distinct Amadjuak FisheritesMaclurites Fauna on southern Baffin Island (Zhang 2012).

- The outcrop of the Boas River Formation on Akpatok Island was not found by the present authors. However, the brown organic-rich argillaceous limestone rubble, representing the Boas River Formation, can be correlated to the "chocolate-coloured limestone" described by Cox (1933a) at an elevation between 143 and $144 \mathrm{~m}$ on the island (Cox 1933b). This elevation is within the lower Foster Bay Formation, as the elevation can be used to identify the stratigraphic unit in the area where the strata are horizontally distributed (Zhang 2018). Thus, the Boas River Formation on Akpatok Island lies within the lower Foster Bay Formation (Zhang 2018).

Therefore, lithostratigraphically the Boas River Formation is an organic rich interval occurring in different mappable stratigraphic units in different areas; and it only represents a brief facies change in the homogeneous unit. As initially defined, it cannot be mapped as an independent stratigraphic unit.

- Biostratigraphy

The Boas River Formation or the organic-rich interval is typically diachronous in the northern Hudson Bay, Hudson Strait and Foxe basins, although a mappable unit can be with diachronism. Based on the graptolite and conodont faunas, the Boas River Formation on Southampton and Akpatok islands can be related to the upper Katian graptolite Dicellograptus anceps and Paraorthograptus pacificus zones and conodont Aphelognathus divergens Zone, but on southern Baffin Island, it can be correlated to the lower Katian graptolite Diplacanthograptus spiniferus Zone and conodont Amorphognathus superbus Zone (Fig. 4). 
- Hudson Bay Lowlands

In the Hudson Lowlands (northern Ontario and northeastern Manitoba), although beyond the coverage of this paper, the stratigraphic control of the Boas River Formation needs a discussion here. It has been located between the Bad Cache Rapids and Churchill River groups for a long time (Sanford and Grant 1990, 1998; Armstrong and Lavoie 2010a, 2010b; Lavoie et al. 2013; Nicolas and Armstrong 2017), but most recently, it has been correlated to the lower Bad Cache Rapids Group (Hahn et al. 2016, 2017). This seems a reasonable correlation, because some conodonts, such as Periodon grandis (Ethington) and Phragmodus undatus Branson and Mehl were reported from the Boas River Formation in drilling cores in Winisk River area in northern Ontario (McCracken 1990); and these species are restricted to the Bad Cache Rapids Group of the lower Katian in the northern Hudson Bay, Hudson Strait and Foxe basins (Zhang, 2011, 2013, 2018). However, the conodonts recovered from the Boas River Formation at Asheweig River section in northern Ontario include Rhipidognathus symmetricus Branson, Mehl and Branson, Amorphognathus duftonus Rhodes and other relatively long-lasting species (McCracken et al. 2013). Rhipidognathus symmetricus was typically recovered from the dolomitic facies Red Head Rapids Formation (Zhang 2011) and its equivalent Foster Bay Formation (Zhang 2013, 2018) in the northern Hudson Bay, Foxe and Hudson Strait basins, and the local Rhipidognathus symmetricus Zone was correlated with North American Midcontinent conodont Aphelognathus divergens Zone of the upper Katian (Zhang 2011, 2013, 2018) in these areas. Thus, based on the known conodonts from northern Ontario (McCracken 1990; MacCracken et al. 2013), the Boas River Formation would be at two different stratigraphic levels. 


\section{Conclusion}

The organic-rich intervals previously named the Boas River Formation, interpreted as being of the same stratigraphic position and the same age, are found in the Upper Ordovician succession exposed on Southampton (northern Hudson Bay Basin), Akpatok (Hudson Strait Basin) and southern Baffin (Foxe Basin) islands. They are, however, at the different stratigraphic position and of the different age, as proven by field observations and the conodonts from these intervals (Zhang 2008, 2011, 2012, 2018) and graptolites reported herein. Lithostratigraphically, the organic-rich intervals are not mappable units, but are intercalated within different mappable stratigraphic units in the areas cited above. In the northern Hudson Bay and Hudson Strait basins, the intervals are in the lower Red Head Rapids Formation, or in its equivalent lower Foster Bay Formation, although in the Foxe Basin the interval is found in the lower Amadjuak Formation. Therefore, the name Boas River Formation is not deemed appropriate for usage in the three basins of northern Canada. In addition, biostratigraphically, the organic-rich intervals are diachronous. In the northern Hudson Bay and Hudson Strait basins, the organic-rich intervals can be correlated to the upper Katian Paraorthograptus pacificus Zone; and that in Foxe Basin to the lower Katian Diplacanthograptus spiniferus Zone.

\section{Acknowledgements}

This study is part of the Hudson Bay-Foxe Project and Hudson Bay-Ungava Project under Natural Resource Canada (NRCan), Lands and Minerals Sector's (LMS) Geo-mapping for Energy and Mineral Program (GEM) 1 and 2, respectively. It is financially supported by both GEM and the Canada-Nunavut Geoscience Office (CNGO). Logistic support in the field was provided by the Polar Continental Shelf Project. Many thanks are extended to the Inuit from 
Coral Harbour, Nunavut and Kuujjuaq, northern Quebec, and the students from University of Calgary and Nunavut Arctic College for their field assistance. Sincere thanks go to D. Lavoie for acting as LMS internal critical reviewer, who provided valuable comments for the first draft, to M.J. Melchin and C.E. Mitchell for acting as the journal's scientific reviewers, and to A. Polat, B. Pratt, and D. Regier for their scientific comments and editorial assistance from the journal. NRCan, LMS contribution number 20170297. 


\section{References}

Armstrong, D.K., and Lavoie, D. 2010a. Re-evaluating the hydrocarbon resource potential of the Hudson Platform: Project introduction and preliminary results from northern Ontario. Summary of Field Work and Other Activities, 2010 Ontario Geological Survey, Open File Report 6260, p. 39-1-39-9.

Armstrong, D.K., and Lavoie, D. 2010b. Re-appraisal of the hydrocarbon resource potential of the Hudson Platform: Project introduction and preliminary results from northern Ontario. Proceedings, Ontario Petroleum Institute, 49th Annual Conference, Niagara Falls, Ontario, v. 49, Technical Paper 15, 12p.

Chen, X., Rong, J.-Y., Mitchell, C.E., Harper, D.A.T., Fan, J.-X., Zhan, R.-B., Zhang, Y.-D., Li, R.-Y., and Wang, Y. 2000a. Late Ordovician to earliest Silurian graptolite and brachiopod biozonation from the Yangtze region, South China, with a global correlation. Geological Magazine, 137 (6): 623-650.

Chen, X., Ni, Y.-N., Mitchell, C.E., Qiao, X.-D., and Zhan, S.-G. 2000b. Graptolites from the Qilang and Yingan formations (Caradoc, Ordovician) of Kalpin, western Tarim, Xinjiang, China. Journal of Paleontology, 74 (2): 282-300.

Chen, X., Fan, J.-X., Melchin, M.J., and Mitchell, C.E. 2005. Hirnantian (latest Ordovician) graptolites from the upper Yangtze Region, China. Palaeontology, 48 (2): 235-280.

Cooper, R.A., and Sadler, P.M. 2012. Chapter 20. The Ordovician Period. In The Geological Time Scale 2012. Edited by F.M. Gradstein, J.G. Ogg, M.D. Schmitz, and G.M. Ogg. Elsevier, Amsterdam (ebook), pp. 489-523.

Cox, I. 1933a. On Climacograptus inuiti sp. nov. and its development. Geological Magazine, 70: $1-19$. 
Cox, I. 1933b. Richmondian trilobites from Akpatok Island. Geological Magazine, 70: 359-373. Elles, G.L. and Wood, E.M.R. 1906. A monograph of British graptolites. Part 5. Monograph of the Palaeontographical Society, 60 (288), 1xxiii-xcvi, 181-216.

Goldman, D., Mitchell, C.E., and Joy, M.P. 1999. The stratigraphic distribution of graptolites in the classic upper Middle Ordovician Utica Shale of New York State: an evolutionary succession or a response to relative sea-level change? Paleobiology, 25 (3): 273-294.

Hahn, K.E., Armstrong, D.K., Turner, E.C., and Nicolas, M.P.B. 2016. Toward a sequence stratigraphic framework of the Ordovician Hudson Bay and Moose River Basins, Northern Ontario. Summary of Field Work and Other Activities 2016, Ontario Geological Survey, Open File Report 6323, p. 28-1-28-10.

Hahn, K.E., Turner, E.C., Armstrong, D.K., and Nicolas, M.P.B. 2017. Late Ordovician chemostratigraphy of the Hudson Bay and Moose River basins. GAC-MAC Kingston 2017 Program with abstracts, v. 40, p. 139 (poster).

Heywood, W.W., and Sanford, B.V. 1976. Geology of Southampton, Coats and Mansel Islands, District of Keewatin, Northwest Territories. Geological Survey of Canada, Memoir 382, 35 p. Jackson, D.E. 1971. Development of Glyptograptus hudsoni sp. nov. from Southampton Island, North-west Territories, Canada. Palaeontology, 14 (3): 478-486.

Lavoie, D., Pinet N., Dietrich, J., Zhang, S., Hu, K., et al., 2013. Geological framework, basin evolution, hydrocarbon system data and conceptual hydrocarbon plays for the Hudson Bay and Foxe basins, Canadian Arctic. Geological Survey of Canada Open File Report OF7363, 200 p. 
Lavoie, D., Pinet N., Dietrich, J., and Chen. Z., 2015. The Paleozoic Hudson Bay Basin in northern Canada: New insights into hydrocarbon potential of a frontier intracratonic basin. American Association of Petroleum Geology Bulletin, 99 (5): 859-888.

Macauley, G. 1986. Geochemistry of the Ordovician Boas oil shale, Southampton Island, Northwest Territories. Geological Survey of Canada Open File Report OF1285, 15 p.

Macauley, G. 1987. Geochemistry of organic-rich Ordovician sediments on Akpatok and Baffin Islands, Northwest Territories. Geological Survey of Canada Open File Report OF1502, $27 \mathrm{p}$.

Macauley, G., Fowler, M. G., Goodarzi, F., Snowdon, L. R., and Stasiuk, L.D. 1990. Ordovician oil shale-Source rock sediments in the central and eastern Canada mainland and eastern Arctic areas, and their significance for frontier exploration. Geological Survey of Canada, Paper 90-14, $51 \mathrm{p}$.

McCracken, A.D. 1990. Report on 38 Ordovician conodont samples from drill core of the Bad Cache Rapids Formation, Boas River Formation, and Churchill River Group in the Hudson Bay Lowlands (Clendenning River Map Sheet, Winisk River area), northern Ontario submitted by B.V. Sanford (GSC-LCSD) and A.C. Grant (GSC-AGC) (NTS 43L/6, 43L/12). Geological Survey of Canada Paleontological Report 03-ADM-1990, 31 p.

McCracken, A.D. 2000. Middle and Late Ordovician conodonts from the Foxe Lowland of southern Baffin Island, Nunavut. In Geology and paleontology of the southeast Arctic Platform and southern Baffin Island, Nunavut. Edited by A.D. McCracken and T.E. Bolton. Geological Survey of Canada Bulletin 557, pp. 13-38. 
McCracken, A.D., and Bolton, T.E. 2000 (ed.). Geology and paleontology of the southeast Arctic Platform and southern Baffin Island, Nunavut. Geological Survey of Canada Bulletin 557, $248 \mathrm{p}$.

McCracken, A.D., Armstrong, D.K., Lavoie, D., Brunton, F.R., and Nicolas, M. 2013. Conodont biostratigraphy of the Hudson Bay and Moose River basins, Ontario and Manitoba. GACMAC Winnipeg Program with abstracts, v. 36, p. 139-140 (poster SS13-P8).

McLaughlin, P.I., Emsbo, P., Desrochers, A., Bancroft, A., Brett, C.E., Riva, J.F., Premo, W., Neymark, L., Achab, A., Asselin, E., and Emmons, M.M. 2016. Refining 2 km of Ordovician chronostratigraphy beneath Anticosti Island utilizing integrated chemostratigraphy. Canadian Journal of Earth Sciences, 53: 865-874.

Melchin M.J. 1987. Upper Ordovician graptolites from the Cape Phillips Formation, Canadian Arctic Islands. Bulletin of the Geological Society of Denmark, 35: 191-202.

Mitchell, C.E., Goldman, D., Cone, M.R., Maletz, J., and Janousek, H. 2003. Ordovician graptolites of the Phi Kappa Formation at Trail Creek, Central Idaho, USA: a revised biostratigraphy. In Proceedings of the Seventh International Graptolite Conference,. Edited by G. Ortega, and F.G. Aceñolaza. INSUGEO, Serie Correlación Geológica, volume 18, pp. 69-72.

Nelson, S.J., and Johnson, R.D. 1966. Geology of Hudson Bay Basin. Bulletin of Canadian Petroleum Geology, 14 (4): 520-578.

Nicolas, M.P.S., and Armstrong, D.K. 2017. Update o Paleozoic stratigraphic in the Hudson Bay Lowland, northeastern Manitoba and northern Ontario. Report of Activities 2017, Manitoba Growth, Enterprise and Trade, Manitoba Geological Survey, p. 133-147. 
Pinet, N., Lavoie, D., Dietrich, J., Hu, K., and Keating, P. 2013. Architecture and subsidence history of the intracratonic Hudson Bay Basin, northern Canada. Earth Science Reviews, 125: $1-23$.

Reyes, J., Jiang, C., Lavoie, D., Milovic, M. Robinson, R., Zhang, S., Armstrong, D., and Mort, A. 2016. Determination of hydrocarbon generation and expulsion temperature of organicrich Upper Ordovician shales from Hudson Bay and Foxe basins using modified hydrous pyrolysis, organic petrography, Rock-Eval and organic solvent extraction. Geological Survey of Canada, Open File 8049, 62 p.

Riva, J. 1969. Middle and Upper Ordovician graptolite faunas of St. Lawrence Lowlands of Quebec, and of Anticosti Island. American Association of Petroleum Geologists Memoir 12: $513-556$.

Riva, J. 1988. Graptolites at and below the Ordovician-Silurian boundary on Anticosti Island, Quebec. Bulletin of the British Museum (Natural History) Geology, 43: 221-237.

Riva, J. 2000. Late Middle-early Late Ordovician graptolites from the base of the Amadjuak Formation, southern Baffin Island, Nunavut. In geology and paleontology of the southeast Arctic Platform and southern Baffin Island, Nunavut. Edited by A.D. McCracken and T.E. Bolton. Geological Survey of Canada Bulletin 557, pp. 237-240. Sanford, B.V., and Grant, A.C. 1990. New findings relating to the stratigraphy and structure of the Hudson Platform. Geological Survey of Canada Current Research, Part D, Paper 901D, pp. 17-30.

Sanford, B.V., and Grant, A.C. 1998. Paleozoic and Mesozoic Geology of the Hudson Bay and Southeast Arctic Platform. Geological Survey of Canada Open File Report OF3595, 2 sheets. 
Sanford, B.V., and Grant, A.C. 2000. Geological framework of the Ordovician system in the southeast Arctic Platform, Nunavut. In Geology and paleontology of the southeast Arctic Platform and southern Baffin Island, Nunavut. Edited by A.D. McCracken and T.E. Bolton. Geological Survey of Canada Bulletin 557, pp. 13-38.

Steward, S., and Mitchell, C.E. 1997. Anticostia, a distinctive new Late Ordovician “glyptograptid” (Diplograptacea, Graptoloida) based on three-dimensionally preserved specimens from Anticosti Island, Quebec. Canadian Journal of Earth Sciences, 34: 215228.

Štorch, P., Mitchell, C.E., Finney, S.C., and Melchin, M.J., 2011. Uppermost Ordovician (upper Katian-Hirnantian) graptolites of north-central Nevada, U.S.A. Bulletin of Geosciences 86 (2): $301-386$.

Wheeler, J.O., Hoffman, P.F., Card, K.D., Davidson, A., Sanford, B.V., Okulitch, A.V., and Roest, W.R. 1997. Geological map of Canada. Geological Survey of Canada, A-series map 1860A.

Williams, S.H. 1982a: Upper Ordovician graptolites from the top Lower Hartfell Shale Formation (D. clingani and P. linearis zones) near Moffat, southern Scotland. Transations of the Royal Society of Edinburgh, Earth Sciences 72: 229-255.

Williams, S.H. 1982b: The late Ordovician graptolite fauna of the Anceps Bands at Dob's Lmn, southern Scotland. Geologica et Palaeontologica 16: 29-56.

Williams, S.H. 1987: Upper Ordovician graptolites from the D. complanatus Zone of the Moffat and Girvan districts and their significance for correlation. Scottish Journal of Geology 23, 65-92. 
Workum, R.H., Bolton, T.E., and Barnes, C.R. 1976. Ordovician geology of Akpatok Island, Ungava Bay, District of Franklin. Canadian Journal of Earth Sciences, 13: 157-178.

Zhang, S. 2008. New insights into Ordovician oil shales in Hudson Bay Basin: their number, stratigraphic position, and petroleum potential. Bulletin of Canadian Petroleum Geology, 56 (4): $300-324$.

Zhang, S. 2011. Late Ordovician conodont biostratigraphy and redefinition of the age of oil shale intervals on Southampton Island. Canadian Journal of Earth Sciences, 48: 619-643.

Zhang, S. 2012. Ordovician stratigraphy and oil shale, southern Baffin Island, Nunavut preliminary field and post-field data. Geological Survey of Canada, Open File 7199, 26 p.

Zhang, S. 2013. Ordovician conodont biostratigraphy and redefinition of the age of lithostratigraphic units on northeastern Melville Peninsula, Nunavut. Canadian Journal of Earth Sciences, 50: 808-825.

Zhang, S. 2018. Upper Ordovician conodont biostratigraphy and revised lithostratigraphy and geological map, Akpatok Island, Ungava Bay, Nunavut. Canadian Journal of Earth Sciences, 55: 52-69.

Zhang, S., and Barnes, C.R. 2007. Late Ordovician-Early Silurian conodont biostratigraphy and thermal maturity, Hudson Bay Basin. Bulletin of Canadian Petroleum Geology, 55 (3): $179-216$.

Zhang, S., and Mate, D.J. 2015. Geological reconnaissance for Ordovician stratigraphy and petroleum potential, Akpatok Island, Nunavut. In Summary of Activities 2014, CanadaNunavut Geoscience Office, pp. 79-88. 


\section{Figure Captions}

Figure 1. Northern part of the Phanerozoic Hudson Bay Basin and adjacent Hudson Strait and Foxe basins (modified from Wheeler et al. 1997). Red triangles point the locations of organicrich intervals in the Upper Ordovician succession.

Figure 2. Stratigraphic nomenclature of Hudson Bay, Foxe, and Hudson Strait basins. Black strips represent organic-rich intervals (unscaled).

Figure 3. The Upper Ordovician organic-rich intervals in northern Hudson Bay, Hudson Strait and Foxe basins and their correlation with the Ordovician chronostratigraphic and biostratigraphic framework adopted from Cooper and Sadler (2012). The black bars represent the stratigraphic position of the Upper Ordovician organic-rich intervals (unscaled). Ea: Eastonian; Bo: Bolindian.

Figure 4. Graptolites from Southampton, Akpatok, and southern Baffin islands. (A) and (B) Anticostia lata (Elles and Wood) from lower organic-rich interval in the lower Red Head Rapids Formation on Southampton Island with (B) showing proximal end, GSC139805 and GSC139806. (C) and (D) Rectograptus socialis (Lapworth) from brown organic-rich argillaceous limestone rubble of the lower Foster Bay Formation on Akpatok Island with (D) showing proximal end, GSC139807 and GSC139808. (E) and (F) Anticostia decipiens (Riva) from brown organic-rich argillaceous limestone rubble of the lower Foster Bay Formation on Akpatok Island, with (F) showing enlargement of black box in (E), GSC139809. (G) and (H) Amplexograptus 
praetypicalis Riva, $(\mathrm{G})$ full rhabdosome from the organic-rich interval of the lower Amadjuak Formation on southern Baffin Island, with $(\mathrm{H})$ showing enlargement of black box in $(\mathrm{G})$, GSC139810. Black bars represent $1 \mathrm{~mm}$. 


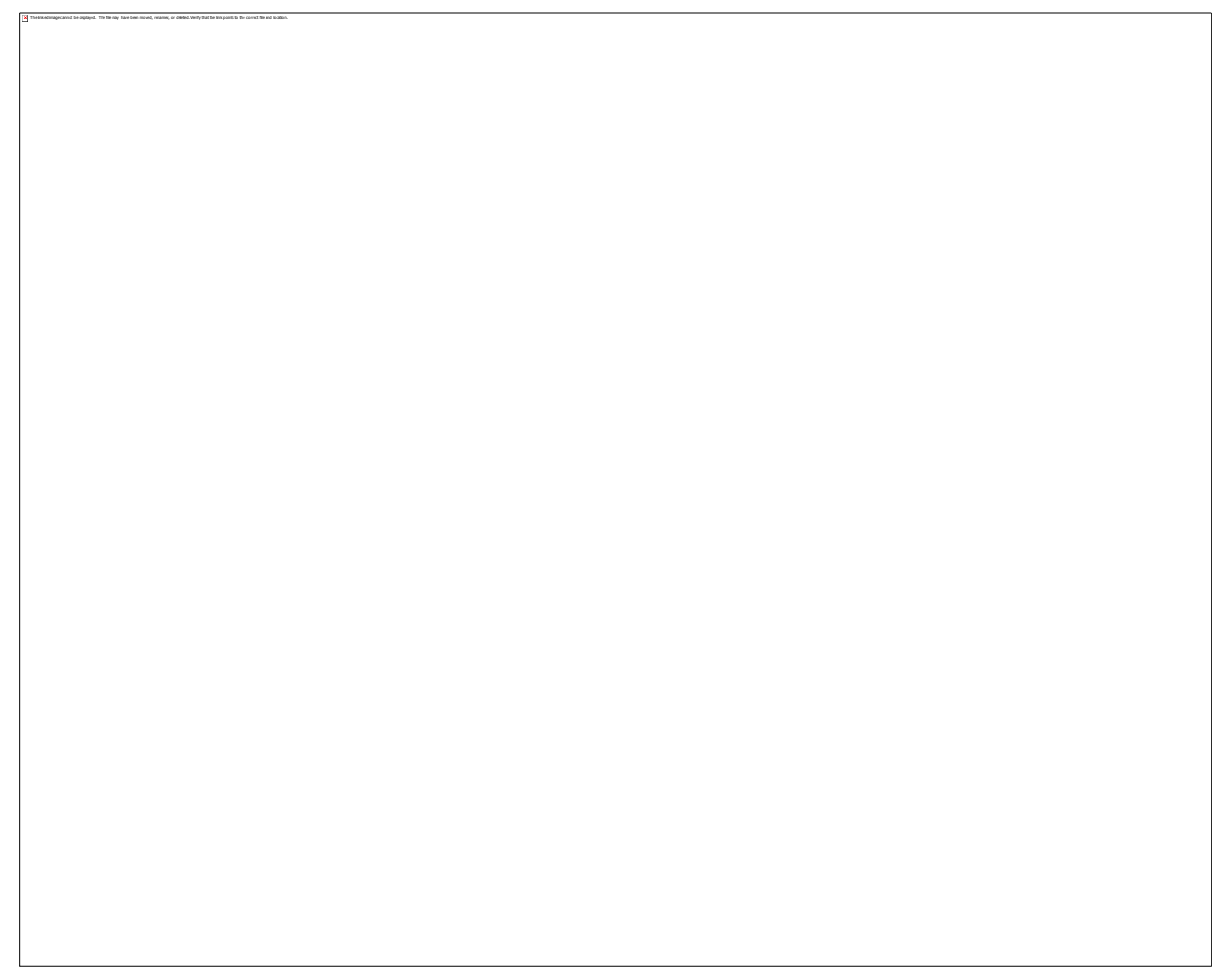

Figure 1

$174 \times 139 \mathrm{~mm}(300 \times 300 \mathrm{DPI})$ 


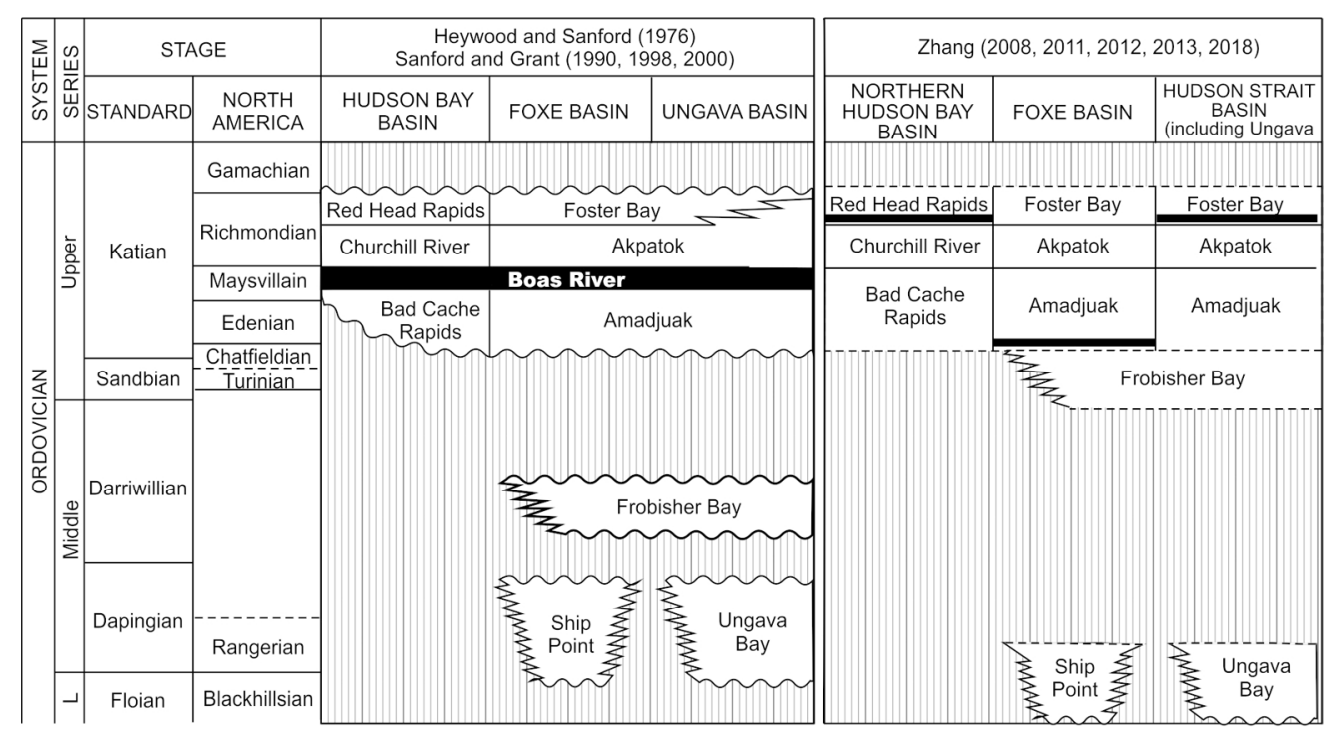

Figure 2

$160 \times 87 \mathrm{~mm}(300 \times 300 \mathrm{DPI})$ 


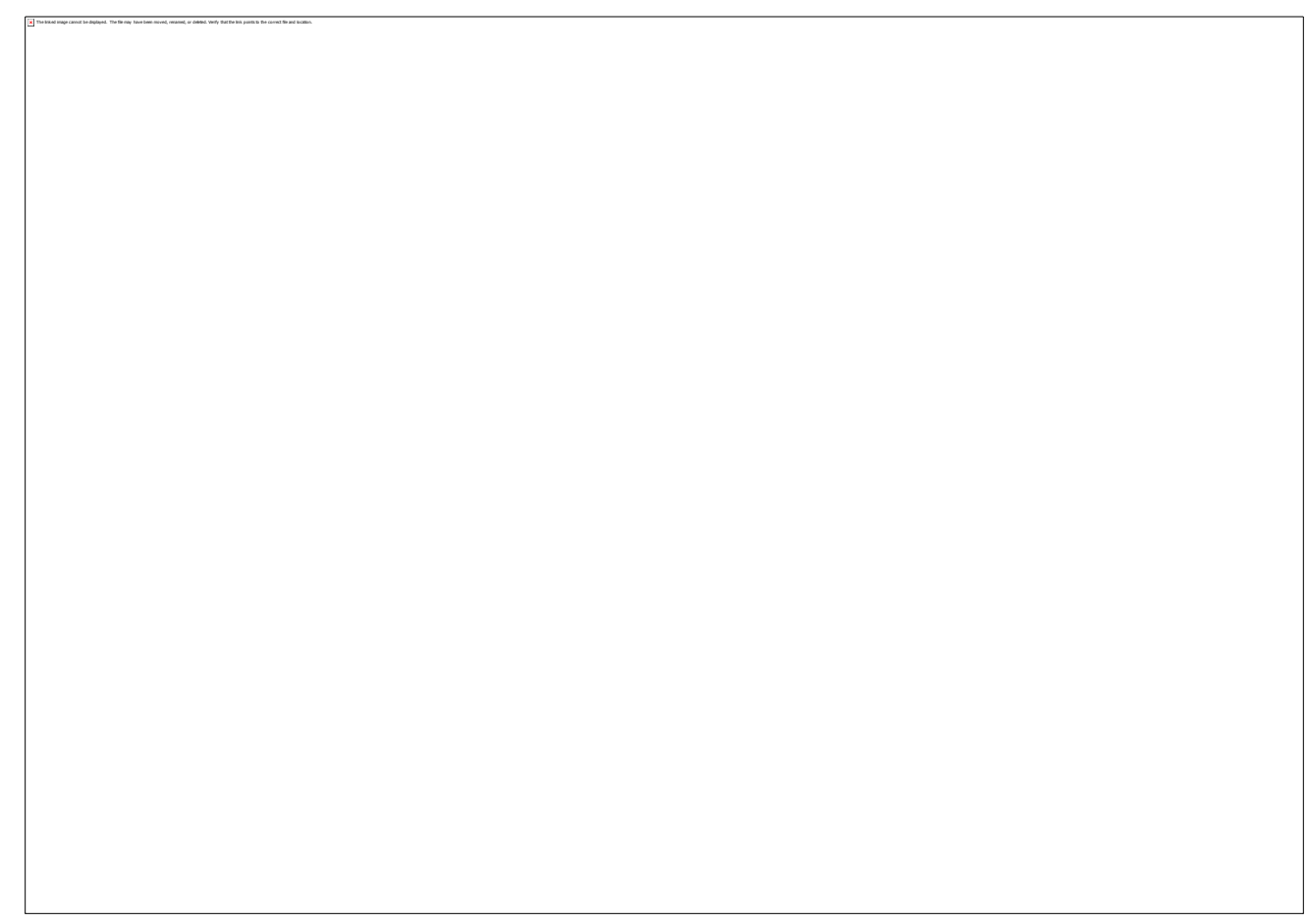

Figure 3

$137 \times 96 \mathrm{~mm}(300 \times 300 \mathrm{DPI})$ 


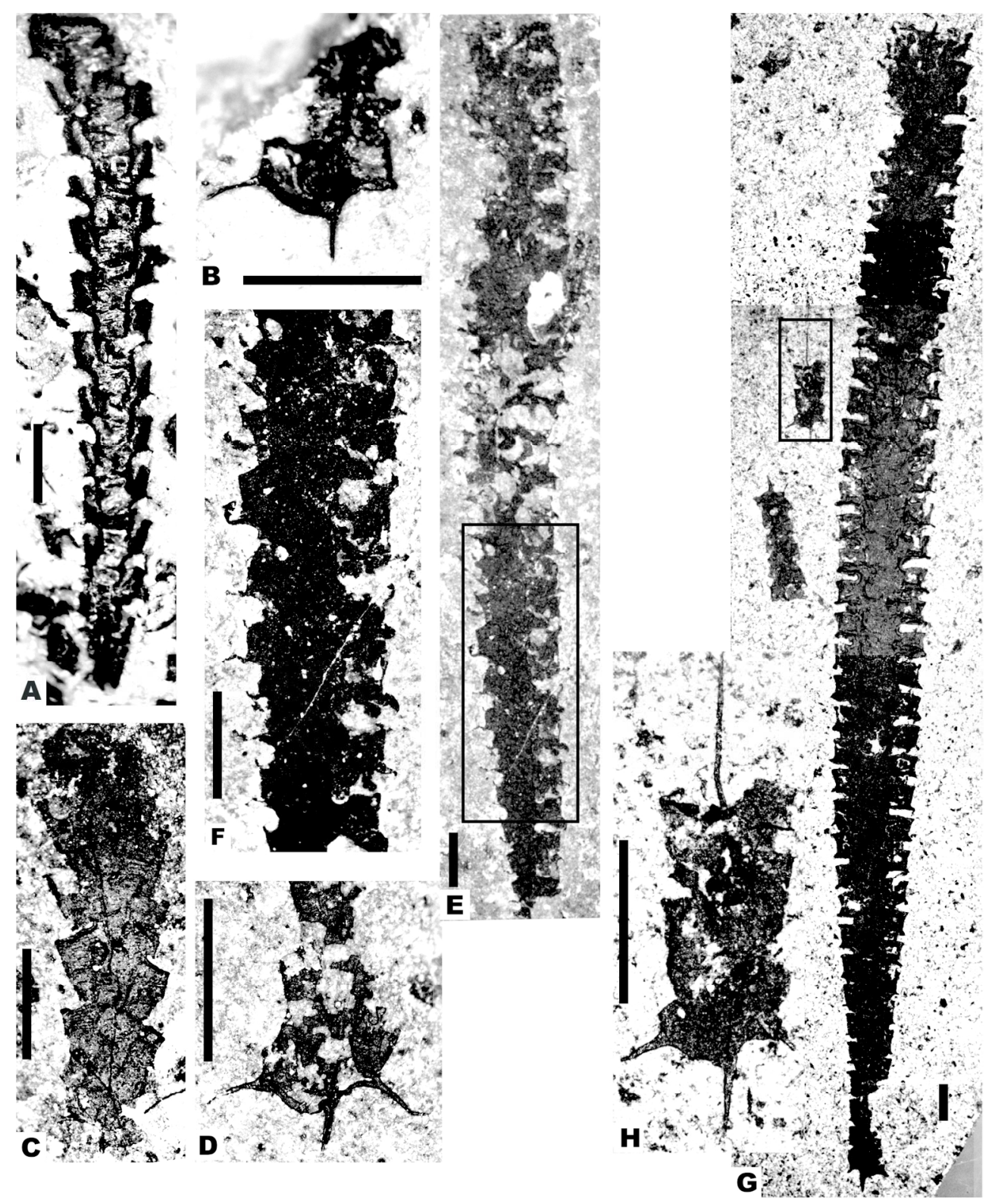

Figure 4

159x195mm ( $300 \times 300$ DPI) 